\title{
ПЕРСПЕКТИВИ УКРАЇНСЬКОЇ ТЕРМІНОГРАФІЧНОЇ КРИТИКИ
}

У статті розкрито потенційні можливості розвитку української термінограбічної критики, що розв'язує питання оцінювання словників термінів, верифікації викладених у них метаданих тощо. Аргументовано такі іï перспективи: виробити власні теоретичні засади оцінювання фахових словників; тексикографічно описати метамову української термінографічної критики; розробити шкалу критичних оцінок спеціальних словників на матеріалі текстів рецензій; розкрити комунікативний потенціал рещензї на термінологічний словник; переглянути недооиінений статус практики оцінювання термінологічних словників; сформувати глобальну українську потужну наукову школу критики тощо. Доведено, що українська термінографічна критика має унікальні перспективи.

Ключові слова: метамова, оцінка, рецензія, текст, термін, термінографічна критика, термінографія, термінологічний словник.

Petrova T. Prospects of Ukrainian Terminographic Criticism. Terminographic criticism is a promising, independent and special direction of terminography, which solves the problem of evaluating terminology dictionaries, verification of metadata set out in them, etc.

Although the Ukrainian terminographic criticism was formed in the early twentieth century, it has not been yet recognized as an independent scientific field and still requires careful study, mainly a clear motivation of its prospects, which determines the relevance of this scientific research.

The aim of the article is to substantiate the prospects of the Ukrainian terminographic criticism as an independent scientific field with the practical application of its results to contribute to the development of national terminography.

Despite the significant practical experience and outlined problems, modern national terminographic criticism as a special interdisciplinary scientific field has great prospects: 1) to develop its own theoretical foundations to estimate professional dictionaries; 2) to describe lexicographically the metalanguage of the Ukrainian terminographic criticism; 3) to develop a critical assessment scale of terminology dictionaries based on the material of the text reviews; 4) to reveal the communicative potential of a terminology dictionary review; 5) to study the phenomenon of linguistic personality of the terminology dictionary reviewer in the critical discourse; 6) to trace the manifestation and signs of a certain critic's individual style on the textual materials of some of his/her evaluative publications about different professional dictionaries; 
7) to establish the global Ukrainian powerful scientific school of terminographic criticism; 8) to review underestimated status of the practice of estimating terminology dictionaries; 9) to establish a central governing body in Ukraine to coordinate and deal with the topical issues of qualified expertizing terminographic sources; 10) to single out and initiate at the state level a special scientific journal with the purpose to purely cover the results of expertizing reference sources. The given list of prospects can be supplemented by actual offers.

The Ukrainian terminology criticism has unique prospects, the implementation of which will provide, first of all, powerful opportunities for its further incessant development as well as a qualitative future for national terminology.

Keywords: metalanguage, estimation, review, text, term, terminographic criticism, terminography, terminology dictionary.

\section{Вступ}

Сьогодні широко й активно вивчають стан та перспективи розвитку чи не всіх українських наук. Найбільш часто термін перспектива вживають у галузях техніки, малювання, малярства, нарисної геометрії тощо на позначення (а) способу зображення на площині або на кривій поверхні об’ємних предметів, (б) правил зображення просторових тіл за допомогою їх проєктування на площину, (в) простору, який можна охопити оком тощо (Білодід, 1975, Т. 6: 332). Розуміння поняття перспективи як наступного розвитку чогось (Білодід, 1975, Т. 6: 332) актуалізується переважно щодо розгляду майбутнього наукових дисциплін, їхніх напрямів, розділів тощо.

В Україні функціюють наукові часописи, на сторінках яких висвітлюють теоретичні й практичні проблеми та власне перспективи таких наукових галузей, як-от: сільського господарства («Агроперспектива», Київ), медицини («Медичні перспективи», Дніпро), права («Европейські перспективи», Київ), освіти й науки («Наша перспектива», Львів), економіки й управління («Проблеми і перспективи економіки та управління», Чернігів), соціальної політики («Перспективи. Соціально-політичний журнал», Одеса) та ін. Викладене дає змогу констатувати, що в сучасній національній науці ключовим $є$ переосмислення перспектив розвитку наукових дисциплін 3 давньою історією і визначення майбутнього для новітніх галузей знань, що в усій сукупності формують перспективи української науки загалом. «Зі становленням української державності актуальності набуває й розуміння специфіки національної науки <...>. Усвідомлюючи 
традиції національної наукової школи, можна об'єктивно оцінити іiі стан та побачити відповідну перспективу» (Космеда, 2017: 176).

Дослідженню різних аспектів й окресленню перспектив критики лексикографічних видань присвячують міжнародні наукові конференції, регулярні засідання Комісії з лексикології і лексикографії Міжнародного комітету славістів, а також наукові збірники, журнали та ін. Відомо, що 2010 р. в Білорусі учасники засідання Комісії з лексикології і лексикографії Міжнародного комітету славістів обговорили проблеми формування нового напряму «критика в слов'янській лексикографії (Гнатюк, 2010: 232). 2012 р. в Інституті української мови Національної академії наук України одночасно відбулися два важливі лексикографічні форуми, у центрі уваги яких були проблеми наукової критики нових словників, передусім критерії оцінювання якості їхніх матеріалів, надійності джерельної бази, нагальна потреба у відновленні норм наукової етики під час використання матеріалів уже виданих словників. На сторінках наукового збірника «Критика у слов'янській лексикографії. Паламарчуку Леоніду Сидоровичу» (Київ, 2012) учені України, Білорусі, Польщі, Росії, Сербії, Словенії, Хорватії детально інформують про результати досліджень, що стосуються (а) критики неспеціальних словників у діахронії і синхронії, а також (б) методів і принципів оцінювання різних типів словників.

У зарубіжному міжнародному щорічнику 3 лексикографії «Wörterbuchkritik - Dictionary Criticism. Series: Lexicographica» (Berlin-Munich-Boston, 2017) науковці Польщі, Німеччини, Данії та інших країн також обговорюють питання, пов'язані із з'ясуванням переваг і недоліків загальномовних словників, тобто лексикографічної критики.

Термінографічна ж критика, як бачимо, усе ще не стала об'єктом вивчення широких наукових кіл, що свідчить про нагальну необхідність звернення на неї належної уваги. Дослідженню початків і своєрідності поступу української термінографічної критики, висвітленню принципів оцінювання спеціальних словників, аналізові специфіки жанру рецензії, що ії репрезентує, а також опису особливостей ії композиції, значенню присвячені поодинокі праці (Петрова, 2018; Петрова, 2019b; Петрова, 2019с; Петрова, 2020b). Хоча вона й сформувалася на початку XX ст., має понад століття історії свого розвитку, однак так 
і не отримала визнання як самостійного наукового напряму і сьогодні потребує ретельного опрацювання, а головно, чіткого мотивування іiі перспектив, що й визначає актуальність цієї наукової студії.

Мета статті - обгрунтувати перспективи української термінографічної критики як самостійного наукового напряму, практичне застосування результатів діяльності якого сприятиме розвитку національної термінографіі; завдання - а) висвітлити теоретичні й практичні проблеми критики термінологічних словників, б) аргументувати практичне застосування результатів їі діяльності, що сприятиме розвитку національної термінографії.

\section{Методи дослідження}

У роботі послідовно застосовано такі загальнонаукові методи, як спостереження, індукція, дедукиія - для систематичного й цілеспрямованого сприйняття досліджуваного метаматеріалу з метою осмислення його специфіки. Концептуально-аналітичний метод використано для кваліфікації і методологійного оцінювання теоретичних засад термінографічної критики; аксіологічний - для з'ясування ціннісних орієнтацій розглядуваного напряму; порівняльно-зіставний - для дослідження через співвідношення особливостей лінгвістичного експертування і рецензування термінологічного словника та виявлення їхніх спільних ознак як практик оцінювання спеціальних текстів з метою перегляду невиправдано заниженого статусу такого рецензування та ін.

\section{Виклад основного матеріалу}

Термінографічна критика й термінографія - це перспективні галузі знань. Нагадаймо, термінографічна критика - самостійний nідрозділ термінографії, у межах якого вивчають особливості конкретних термінологічних словників, а також форми та способи лексикографічного репрезентування термінологічного матеріалу (Петрова, 2018: 210). Водночас це особливий сформований науковий напрям, що розв'язує питання (1) оцінювання словників термінів, (2) верифікації метаданих, викладених у спеціальних джерелах.

Українська термінографічна критика розвивалася фактично незалежно й накопичила достатній теоретичний потенціал та практичний досвід (iї витоки сягають початку XX ст.), щоб повноправно 
претендувати не лише на визнання іiі самостійності й своєрідності, а й на осмислення їі важливих завдань та аргументування широких перспектив.

Утім розглядати перспективи певного наукового напряму потрібно, відштовхуючись від його “гострих” проблем, вирішення яких розширить горизонт можливостей його розвитку. Сучасна українська критика термінологічних словників має низку важливих проблем, які розподіляємо на дві групи - теоретичні й практичні.

Теоретичні проблеми зумовлені формуванням методологійних засад аналізованого напряму, зокрема: а) з’ясування місця критики спеціальних словників у системі сучасних наук; б) виділення основних критеріїв оцінювання довідкових видань; в) розроблення поетапного алгоритму експертування термінографічних джерел; г) створення інваріантної моделі композиції рецензії на термінологічний словник та ін.

Практичні проблеми пов'язані з прагматикою термінографічної критики, зокрема: а) виявлення джерел, що містять рецензії на фахові словники; б) типологізування рецензій на спеціальні видання за різними ознаками; в) виокремлення різних груп критиків спеціальних словників (критики-термінографи, критики-нетермінографи) тощо. Отже, перспективи термінографічної критики можуть визначатися насамперед вирішенням теоретичних і практичних ії питань, що, зрозуміло, взаємопов'язані.

Попри вагомий практичний досвід і водночас окреслені проблеми сучасна національна термінографічна критика як особливий синтетичний науковий напрям має неабиякі перспективи. Виділімо Й мотивуймо кожну окремо.

1. Виробити власні теоретичні засади критики фахових словників, оскільки ії практика “випереджає” теорію. Термінографічна критика як самостійний складник термінографії має власну методологійну основу: об'єкт (спеціальні словники), предмет (аналіз фахових видань щодо застосування принципів і методів їх укладання), завдання (1/ критичне оцінювання фахових словників стосовно дотримання принципів їх побудови, специфіки їх мега-, макро- й мікроструктур; 2/ експертування, скероване на вияв достовірності викладених наукових знань, необхідності їх уточнення чи коригування), методи (лексикографічного аналізу словника, кількісного аналізу, 
порівняльний), функцї (оцінювальна - аналіз словника з виокремленням його достоїнств та недоліків; інформативно-довідкова - поширення, рекламування відомостей про вихід термінографічного видання), жанр (рецензія на термінологічний словник).

Спираючись на викладене методологійне підгрунтя термінографічної критики, сформулюємо ії теоретичні засади: 1) об'єктивно й поліаспектно оцінювати якість термінографічного джерела; 2) під час експертування словника (а) застосовувати основні критерії його рецензування (критерій оцінювання концепції словника, критерій оцінювання кількості інформації у виданні, критерій оцінювання якості інформації в словнику, критерій оцінювання ефективності репрезентування інформації в спеціальному виданні, критерій установлення наукової цінності словника) та додаткові критерії (критерій відповідності словника запитам користувачів і критерій наслідування лексикографічних традицій), (б) дотримуватися алгоритму поетапного експертування мега-, макро- й мікроструктури термінографічного видання (Петрова, 2018: 211-212), при цьому (в) аналізуючи терміноодиниці щодо відповідності критеріям термінологічної нормативносmi (системний критерій, національний критерій, критерії функційної доцільності й когнітивно-комунікативної значущості). Дотримання цих теоретичних засад сформує традиції термінографічної критики й сприятиме продукуванню високоякісних термінографічних джерел.

2. Розробити шкалу критичних оцінок термінологічних словників на матеріалі текстів рецензій. Оцінка $є$ «текстовою категорією і має функційно-комунікативну спрямованість», «створює інтенсіональний контекст “текст у тексті”. Вона $€$ певним “модусом” означення ситуації, і сама характеризується різними модальностями. По-перше, оцінка може бути репрезентована різним ступенем категоричності, по-друге, вона може маніфестуватися в модусах бажання, необхідності, примусу, по-третє, вона може виступати в модусі об'єктивної оцінки, а може об'єктивуватися, пропонуватися як спільна, загальна думка тощо» (Космеда, 2000: 289). Основною опозицією шкали є дихотомія 'схвалення / осуд', що позначають позитивну чи негативну оцінку термінографічного видання. Звісно, центром оцінної шкали, тобто призмою, через яку відбувається оцінювання термінологічного словника, є міркування й судження критика. «Суб'єкт сам створює шкалу оцінки з полюсами “добре” / “погано” та зоною нейтрального, 
де позитивні й негативні ознаки врівноважуються залежно від уявлень про норму» (Халіман, 2019: 27). Зведена шкала оцінок (а) засвідчить конструктивність / деструктивність, якість / кількість критики, (б) відобразить можливий спектр критики, (в) репрезентує градацію нейтральних й емоційних оцінок, а головно, (г) дасть змогу виробити в межах шкали “аксіологічну рамку”, за якою доцільно експертувати параметри фахових словників.

\section{3. Розкрити комунікативний потенціал рецензї на терміно-} логічний словник. Критика - це рушійна сила прогресу в суспільстві та науці. Розвиток критичного дискурсу зумовлює вдосконалення жанру рецензіі, що дає змогу вести фахові дискусії, полеміку, суперечки не лише у формі діалогу, а й полілогу.

На критику фахових словників їхні автори переважно не реагують, тобто не публікують відповіді рецензентові. Це вказує, як правило, на їхню згоду із зауваженнями експерта, визнання допущених помилок і неточностей, бажання їх нейтралізувати (див. Петрова, 2019a). Однак, відповідаючи на критику, автор словника вступає в діалог з рецензентом, так “зав'язується” професійне спілкування, викликане незгодою упорядника словника з негативними коментарями, оцінкою, зауваженнями. У такому разі виникає науковий діалог. Водночас до обговорення можуть приєднатися й незалежні, але зацікавлені особи - науковці, фахівці, які, “захищаючи” значущість словника, аргументують його переваги й цінності. Відповідно розгортається полеміка, що набуває форми різновекторного обговорення - наукового полілогу. На жаль, зафіксовано поодинокі приклади такого полілогу, головно у 20-х рр. XX ст. Розвивання наукових дискусій через рецензії у відповідних публікаціях, тобто в статті-відповіді автора словника й статті-захисті небайдужого фахівця (фахівців), дуже важливі, оскільки в спільному обговоренні й зіткненні поглядів народжується істина. Рецензія на термінологічний словник має потужний потенціал наукової комунікації і перспективу відродження цієї традиції.

4. Вивчити феномен лінгвоособистості (лінгвоперсони) рецензента термінологічного словника в критичному дискурсі. У сучасному мовознавстві «лінгвоперсону можна розкрити через аналіз іiі мовного маскування (модус persona), розгляд ії внутрішньої сутності (студіювання дискурсивних практик - модус per se), вивчення лінгводуховного стану, ціннісних орієнтувань (модус perzon), простеження 
єдності світів і реалізації мовної особистості в інших (модус персонального)» (Загнітко, 2017: 6). Водночас науковці виокремлюють кілька підходів до аналізу мовної особистості, як-от: а) психологічний (особливості характеру й особливості його комунікативного вияву); б) соціологічний (розгляд індикаторів мовної особистості, корпоративних груп тощо, індикаторів комунікативної поведінки мовної особистості, малих груп, установлення параметрів узусних та мовленнєвих обмежень); в) культурологійний (моделювання лінгвокультурних типів як упізнаваних національних феноменів на зразок украӥнський козак, польський шляхтич, американський бізнесмен); г) лінгвістичний (комунікативна поведінка носіїв різних суспільних категорій, установлення параметрів комунікативної поведінки, “розпізнавання” мовленнєво-комунікативних типів, дослідження закономірностей реалізації комунікативних стратегій і тактик, розгляд особливостей вияву мовної особистості в різних іiі дискурсах (Космеда, 2012: 57-68). Дослідження мовної особистості, або лінгвоперсони рецензента (критика / експерта) термінологічного словника, може стати перспективним інтегральним вектором вивчення і термінографічної критики, і лінгвоперсонології - лінгвоперсонологія критика.

5. Відстежити прояв й ознаки ідіостилю на текстовому матеріалі сукупності оцінювальних публікацій одного критика стосовно різних фахових словників. Наприклад, А. Загнітко видав збірник власних рецензій на різні наукові видання, зокрема й термінологічні словники (Загнітко, 2014). Аналіз критичних публікацій цього збірника дасть змогу виокремити індивідуальні риси критичного дискурсу А. Загнітка.

6. Лексикографічно описати метамову украӥнської термінографічної критики. Спеціальна мова аналізованого напряму потребує визначення ії меж, а відповідно, кодифікування й уніфікування. Поняттєво-термінологічний апарат термінографічної критики структурований і різнорівневий, оскільки розглядувана дисципліна, як і кожна класична наука, має три розділи: 1) теорія термінографічної критики, 2) історія термінографічної критики й 3) практика термінографічної критики. Метамова спеціальної критики за понад століття iii розбудови як особливого наукового напряму сформована, утім залишається “відкритою” системою. Значна кількість її термінодиниць, як з'ясувалося, ретермінологізована з різних суміжних наук, у яких 
спільна теоретико-методологійна основа, зокрема: термінографії, термінознавства, мовознавства, лінгвоаксіології, лінгвістичної експертології, наукової комунікації, джерелознавства та ін. (Петрова, 2020а; Петрова, 2021). Для всебічного відображення терміносистеми критики фахових словників важливо також відстежити наявні епідигматичні й парадигматичні зв'язки між поняттями всередині системи й між іншими терміносистемами. Словник термінографічної критики (1) стане "паспортом" досліджуваної науки, (2) кодифікує ії метаодиниці, (3) уніфіковано дефініює їхні поняття, (4) сприятиме ефективній комунікації серед професіоналів, критиків, науковців та ін.

7. Сформувати глобальну украӥнську національну наукову школу термінографічної критики, вагомі здобутки якої будуть систематизуватися й примножуватися, поширюючи кращі традиції і цінності. Критиків термінологічних словників треба готувати. Це можуть бути наукові школи, що мають різні типологійні форми, якот: «а) науково-освітня школа, тобто вища школа; б) дослідницький колектив; в) науковий напрям, що має за певних соціально-історичних умов національний або й інтернаціональний характер» (Космеда, 2017: 177). Школою може бути й колектив учених, термінографів, визнаних науковою громадськістю, що експертують фахові словники за єдиними принципами під керівництвом відомого вченого або вчених, наприклад знаних мовознавців - А. Загнітка, Т. Космеди, I. Кочан, Л. Симоненко, В. Широкова та ін. Представники ж наукової школи (1) забезпечать іï стійкість в умовах динамічного розвитку національної, європейської та світової науки, зберігаючи історію, традиції та розвиваючи “бренд” наукової школи, (2) здійснять особистий вклад у ії формування й розвиток (через публікації монографій, статей, рецензій, а також здійснюючи пошук нових напрямів / векторів спеціальної критики тощо), (3) з метою вдосконалення ії положень залучать до наукової співпраці й міжнародної діяльності інших науковців українських і закордонних шкіл термінографічної критики. Активна діяльність і напрацювання наукової школи забезпечать (а) не спорадичний, а стійкий і успішний розвиток термінографічної критики, (б) визнання наукових досягнень іï представників, (в) створить їй авторитет і (г) гарантує формування статусу впливової організації.

8. Переглянути недооцінений статус практики оцінювання термінологічного словника. Традиційно зміст терміна лінгвістичне 
експертування, на відміну від суті терміна рецензування термінологічного словника, сприймається як дослідження вищого рівня кваліфікації. Однак проведений порівняльно-зіставний аналіз засвідчив рівнозначність їхніх статусів за особливостями, призначенням і функціями (Петрова, 2020с). Це зумовлює необхідність визнати практику оцінювання термінологічного словника не як рецензування, а як різнорівневе експертування термінографічного видання. Відповідно, на позначення процесу аналізування якості фахового словника доречно використовувати термін термінографічне експертування, для найменування виконавця цього процесу - експерт термінограбічного видання, а на позначення підсумкової оцінки фахового словника термінограбічна експертиза. Переосмислення змісту базових понять стимулюватиме розвиток термінографічної критики, приверне увагу до ii нагальних проблем, а також дасть змогу належно, гідно й поновому кваліфікувати одну з особливих форм сучасного наукового критичного оцінювання термінологічного словника як термінографічне експертування.

9. Створити в Украйні центральний керівний орган, що займатиметься актуальними питаннями квалібікованого експертування термінографічних джерел і координуватиме їх. Безумовно, нагальним $є$ утворення координаційного органу експертування термінологічних словників, завданнями якого були 6 (а) відстеження виходу у світ словника, (б) об’єктивне встановлення його якості та (в) перевидання вже надрукованого. Науково-експертна, методологійна й теоретична робота з лінгвістичної експертології в Україні здійснюється насамперед державними установами, зокрема Українським бюро лінгвістичних експертиз (засноване 2004 р.), Українським мовно-інформаційним фондом, що входять до складу Національної академії наук України, приватними організаціями тощо. Центрів чи установ, що займалися б оцінюванням термінографічних джерел в Україні, на жаль, на сьогодні не існує. Однак відомо, що 2013 р. створено Словникову комісію Міністерства освіти і науки України, завдання якої - (1) проведення експертизи словників української мови, двомовних видань щодо їхньої якості, доцільності й (2) затвердження та рекомендування до опублікування як загальнообов'язкових для використання в державних органах та в органах місцевого самоврядування, тобто здійснення допублікаційного експертування. Очевидно, 
$€$ потреба стимулювати створення на державному рівні за повного фінансового забезпечення відповідального органу, компетенцією якого було б координування роботи експертів термінологічних словників з дотримання єдиних методології і принципів їхнього аналізування не лише на допублікаційному, але й постпублікаційному етапах.

10. Виокремити й започаткувати спеціальний науковий часопис державного рівня, призначенням якого стануть суто (1) висвітлення результатів експертування довідкових джерел, що вже побачили світ, а також (2) інструктування щодо принципів їхнього впорядкування. Дозволимо собі запропонувати його назву: «Українська термінографічна критика» або «Критика термінографічних джерел» тощо. Активне функціювання цього журналу дасть змогу (а) згуртувати в єдиному науковому виданні діяльність сучасних експертів фахових словників, (б) виявити “білі плями” в теорії чи практиці термінографії і термінографічної критики, (в) систематизувати аргументовані зауваження критиків щодо репрезентування структурних параметрів видань задля вдосконалення теоретико-методологійних засад метатермінографії, а відповідно, якісного створення новітніх довідкових праць, (г) окреслити “горизонти” й перспективи спеціальної критики, а також термінографії тощо.

Поданий перелік перспектив не є повним чи завершеним, він “відкритий” i, безперечно, може бути доповнений актуальними пропозиціями, однак кожна потребує глибокого осмислення, рішучості й завзятості ії втілення.

\section{Висновки}

Сьогодні можна лише припускати, за якими напрямами розвиватиметься термінографічна критика, та прогнозувати актуальні й перспективні вектори іiї розбудови, однак це жодним чином не повинно бути обов'язковим керівництвом для дослідницької діяльності. Отже, українська термінографічна критика має унікальні перспективи, зреалізування яких забезпечить насамперед потужні можливості ії подальшого невпинного розвитку, а також якісне майбутнє української національної термінографії.

У подальшому доцільно вивчити шкалу критичних оцінок термінологічних словників на матеріалі текстів рецензій для (а) з'ясування, наскільки критика може бути конструктивною / деструктивною, 
(б) репрезентування можливого спектра критики й градації нейтральних чи емоційних оцінок, а головно, (в) розроблення в межах шкали “аксіологічної рамки”, за якою доречно аналізувати параметри фахових словників.

\section{ЛІТЕРАТУРА}

1. Білодід, І. К. (Ред.) (1970-1980). Словник української мови. (Т. 1-11). Київ: Наук. думка. 2. Гнатюк, I. (2010). Пріоритетні напрями досліджень з лексикології та лексикографії в сучасній славістиці. Лексикографічний бюлетень, 19, 232-238. 3. 3агнітко, А. П. (2014). Сучасна лінгвістика: погляди та оцінки. Донецьк: ДонНУ. 4. 3агнітко, А. (2017). Теорія лінгвоперсонологіï. Вінниця: Нілан-Лтд. 5. Космеда, Т. (2000). Аксіологічні аспекти прагмалінгвістики: формування і розвиток категорії оиінки. Львів: ЛНУ ім. Івана Франка. 6. Космеда, Т. А. (2012). Ego i Alter Ego Tapaca Шевченка в комунікативному просторі щоденникового дискурсу. Дрогобич: Коло. 7. Космеда, Т. (2017). Функційне навантаження наукової мовознавчої школи в сучасному просторі університетської системи. Лінгвістичні студіï, 34, 176-183. 8. Петрова, Т. (2020а). Зони перетину метамов термінографічної критики й лінгвістичноі експертології в українському мовознавстві. Acta Polono-Ruthenica, 3 (XXV), 191-200. https://doi. org/10.31648/apr.5898. 9. Петрова, Т. О. (2020b). Особливості композиції рецензії на термінологічний словник. Лінгвістичні дослідження, 52, 177-193. https://doi.org/ 10.34142/23127546.2020.52.17. 10. Петрова, Т. (2019a). Рецензія на термінологічний словник: експертиза, професійний діалог і наукова дискусія. Лінгвістичні студіï, 38, 84-88. DOI: 10.31558/1815-3070.2019.38.13. 11. Петрова, Т. (2019b). Рецензія на термінологічний словник як жанр критичного субдискурсу. Наук. пр. Кам'янещь-Поділ. наи. ун-ту імені Івана Огієнка. Серія «Філологічні науки», 50, 133-139. DOI: 10.32626/23099771.2019-50-133-139. 12. Петрова, Т. О. (2019c). Теоретико-практичне значення рецензій на українські термінологічні словники кінця XX ст. - поч. XXI ст. Проблеми загального і слов'янського мовознавства, 3, 96-106. https://doi.org/10.15421/251913. 13. Петрова, Т. (2020c). Современные практики оценки специальных текстов: лингвистическая и терминографическая экспертизы. Jezikoslovni zapiski, 26 (2), 155-171. https://doi.org/10.3986/JZ.26.2.11. SNIP 0,67. 14. Петрова, T. (2021). Терминологические параллели в метаязыке славянской терминографической критики. Przeglad Rusycystyczny, 1 (173), 132-150. DOI: 10.31261/pr.9093. 15. Петрова, Т. О. (2018). Українська термінографічна критика: від витоків до сучасності. Наук. вісн. Наи. ун-ту біоресурсів і природокористування України. Серія «Філологічні науки», 292, 208-217. 16. Халіман, О. В. (2019). Граматика оцінки: морфологічні категорії украйнської мови. Харків: Майдан.

\section{REFERENCES}

1. Bilodid, I. K. (Red.) (1970-1980). Slovnyk ukrainskoi movy [Dictionary of the Ukrainian language]. (T. 1-11). Kyiv: Nauk. dumka. 2. Hnatiuk, I. (2010). Priorytetni napriamy doslidzhen $\mathrm{z}$ leksykolohii ta leksykohrafii $\mathrm{v}$ suchasnii slavistytsi [Priority areas of research in lexicology and lexicography in modern Slavic studies]. Leksykohrafichnyi biuleten - Lexicographic bulletin, 19, 232-238. 3. Zahnitko, A. P. (2014). Suchasna 
linhvistyka: pohliady ta otsinky [Modern linguistics: views and assessments]. Donetsk: DonNU. 4. Zahnitko, A. (2017). Teoriia linhvopersonolohii [Theory of linguopersonology]. Vinnytsia: Nilan-Ltd. 5. Kosmeda, T. (2000). Aksiolohichni aspekty prahmalinhvistyky: formuvannia i rozvytok katehorii otsinky [Axiological aspects of pragmalinguistics: formation and development of the evaluation category]. Lviv: LNU im. Ivana Franka. 6. Kosmeda, T. A. (2012). Ego i Alter Ego Tarasa Shevchenka v komunikatyvnomu pros-tori shchodennykovoho dyskursu [Taras Shevchenko's Ego i Alter Ego in the communicative space of a diary discourse]. Drohobych: Kolo. 7. Kosmeda, T. (2017). Funktsine navantazhennia naukovoi movoznavchoi shkoly $\mathrm{v}$ suchasnomu prostori universytetskoi systemy [Functional load of scientific linguistic school in the modern space of the University system]. Linhvistychni studii - Linguistic studies, 34, 176-183. 8. Petrova, T. (2020a). Zony peretynu metamov terminohrafichnoï krytyky y linhvistychnoi ekspertolohiï v ukraïnskomu movoznavstvi [Intersection areas of metalanguages of terminographic criticism and linguistic expertology in Ukrainian linguistics]. Acta Polono-Ruthenica, 3 (XXV), 191-200. https:// doi.org/10.31648/apr.5898. 9. Petrova, T. O. (2020b). Osoblyvosti kompozytsii retsenzii na terminolohichnyi slovnyk [Composition features of terminology dictionary review]. Linhvistychni doslidzhennia - Linguistic research, 52, 177-193. https://doi.org/10.34142/ 23127546.2020.52.17/. 10. Petrova, T. (2019a). Retsenziia na terminolohichnyi slovnyk: ekspertyza, profesiinyi dialoh i naukova dyskusiia [Review of a terminological dictionary: examination, professional dialogue and scientific discussion]. Linhvistychni studii Linguistic studies, 38, 84-88. DOI: 10.31558/1815-3070.2019.38.13. 11. Petrova, T. (2019b). Retsenziia na terminolohichnyi slovnyk yak zhanr krytychnoho subdyskursu [The review of a terminology dictionary as a critical sub-discourse genre]. Nauk. pr. Kamianets-Podil. nats. un-tu imeni Ivana Ohiienka. Seriia «Filolohichni nauky» - Scientific works of Ivan Ogienko Kamyanets-Podilsky National University. Series «Philological sciences», 50, 133-139. DOI: 10.32626/2309-9771.2019-50-133-139/. 12. Petrova, T. O. (2019c). Teoretyko-praktychne znachennia retsenzii na ukrainski terminolohichni slovnyky kintsia XX st. - poch. XXI st. [Theoretical and practical value of the reviews on Ukrainian terminology dictionaries of the late $\mathrm{XX}^{\text {th }}$ and the early XXI ${ }^{\text {st }}$ centuries]. Problemy zahalnoho i slovianskoho movoznavstva Problems of general and Slavic linguistics, 3, 96-106. https://doi.org/10.15421/251913. 13. Petrova, T. (2020c). Sovremennye praktiki ocenki special'nyx tekstov: lingvisticheskaya $\mathrm{i}$ terminograficheskaya e'kspertizy [Current practices for estimating special texts: linguistic and terminographic expertising]. Jezikoslovni zapiski - Linguistic notes, 26 (2), 155-171. https://doi.org/10.3986/JZ.26.2.11. SNIP 0,67. 14. Petrova, T. (2021). Terminologicheskie paralleli v metayazyke slavyanskoj terminograficheskoj kritiki [Terminological parallels in the metalanguage of Slavic terminographic criticism]. Przeglad Rusycystyczny, 1 (173), 132-150. DOI: 10.31261/pr.9093. 15. Petrova, T. O. (2018). Ukrainska terminohrafichna krytyka: vid vytokiv do suchasnosti [Ukrainian termonografical criticism: from origin to modern times]. Nauk. visn. Nats. un-tu bioresursiv i pryrodokorystuvannia Ukrainy. Seriia "Filolohichni nauky» - Scientific Bulletin of the National University of Life and Environmental Sciences. Series «Philological sciences», 292, 208-217. 16. Khaliman, O. V. (2019). Hramatyka otsinky: morfolohichni katehorii ukrainskoi movy [Grammar of assessment: morphological categories of the Ukrainian language]. Kharkiv: Maidan. 
Петрова Тетяна Олексївна - кандидат філологічних наук, доцент, доцент кафедри мовних дисциплін, Харківський національний аграрний університет імені В. В. Докучаєва; п/в «Докучаєвське-2», Харківський район, Харківська область, 62483, Україна.

Tel.: +38-095-574-76-41

E-mail: t.petrova.science@gmail.com

http://orcid.org/0000-0002-9534-9891

Petrova Tetiana Oleksiivna - Candidate of Philological Sciences (Ph.D.), Docent, Associate Professor at the Department of Linguistic Disciplines, V. V. Dokuchaiev Kharkiv National Agrarian University; p/o «Dokuchaievske-2», Kharkiv district, Kharkiv region, 62483, Ukraine.

Надійшла до редакції 25 березня 2021 року

\section{CITATION}

ДСТУ 8302:2015: Петрова Т. О. Перспективи української термінографічної критики. Лінгвістичні дослідження: зб. наук. пр. Харк. нац. пед. ун-ту імені Г. С. Сковороди. Харків, 2021. Вип. 54. Ч. I. С. 229-242. DOI: https://doi.org/10.34142/23127546. 2021.54.1.20

APA: Петрова, Т. О. (2021). Перспективи української термінографічної критики. Лінгвістичні дослідження, 54 (I), 229-242. DOI: https://doi.org/10.34142/23127546.2021. 54.1.20 